\title{
Article
}

\section{Treatment of low vitamin D levels in children}

Davies, Janice Anne

Available at http://clok.uclan.ac.uk/24295/

Davies, Janice Anne (2018) Treatment of low vitamin D levels in children. Nurse Prescribing, 16 (9). pp. 416-417. ISSN 2052-2924

It is advisable to refer to the publisher's version if you intend to cite from the work.

For more information about UCLan's research in this area go to http://www.uclan.ac.uk/researchgroups/ and search for < name of research Group>.

For information about Research generally at UCLan please go to http://www.uclan.ac.uk/research/

All outputs in CLoK are protected by Intellectual Property Rights law, including Copyright law. Copyright, IPR and Moral Rights for the works on this site are retained by the individual authors and/or other copyright owners. Terms and conditions for use of this material are defined in the policies page.

\section{CLoK}

Central Lancashire online Knowledge www.clok.uclan.ac.uk 
Vitamin $D$ is involved in the regulation of blood calcium and phosphate levels and is essential for healthy bone growth. Deficiency of vitamin D in infants can cause seizures and cardiomyopathy, in children it can lead to rickets and poor growth, and in adults it can lead to osteomalacia. In older adults it can lead to osteoporosis. It can cause muscle weakness at any age. (Royal College of Paediatrics and Child Health (RCPCH), 2013)

There are several risk factors for low vitamin D levels (RPCPH, 2013):

\begin{tabular}{|l|l|}
\hline Increased need & Pregnancy \\
\hline & Twins or multiple births \\
\hline & Adolescents \\
\hline & infants \\
\hline Reduced sun exposure & obesity \\
\hline & Northern latitude eg UK \\
\hline & $\begin{array}{l}\text { Asian people - dark skin needs more sunshine } \\
\text { to make vitamin D }\end{array}$ \\
\hline & Wearing concealing clothing \\
\hline & Immobility eg inpatients \\
\hline Limited diet & Excessive use of sun block \\
\hline & vegetarian or vegan \\
\hline & Prolonged breastfeeding \\
\hline & Exclusion diets eg milk allergy \\
\hline & Liver or renal impairment \\
\hline & Malabsorption \\
\hline & Some medicines eg anti-TB drugs, some \\
anticonvulsants
\end{tabular}

The main source of vitamin $D$ is sunshine. The skin manufactures vitamin $D$ when the sun is high in the sky - from March to October for most of the UK; April to September in Scotland. Dietary sources are minimal - eggs and oily fish are where the most abundant supplies can be found. Some foods such as margarine and breakfast cereals are fortified, plus formulae milk. Cow's milk and breast milk contain very low levels of vitamin D. (RCPCH, 2013)

Vitamin $D$, regardless of whether it is sourced from sunshine or diet, is converted in the liver to 25hydroxyvitaminD and this is subsequently converted to the active compound 1,25dihydroxyvitaminD in the kidneys. Treatment of vitamin $D$ levels is by the administration of simple Vitamin D. The activated form of vitamin D should not be used in vitamin D deficiency - this is reserved for use by specialists in the management of complex cases or renal disease. (RCPCH, 2013)

Vitamin D levels are classified by 25 hydroxyvitaminD levels as follows: 
below $25 \mathrm{nmol} / \mathrm{L}$ - deficiency

25-50nmol/L - insufficiency

above $50 \mathrm{nmol} / \mathrm{L}-$ normal

Some laboratories use higher levels so you should use your local reference ranges when treating patients.

(RCPCH, 2013)

The RCPCH (2013) guidelines do not recommend any specific commercial product. The onus is on the prescriber to check their local guidelines for product choice. Access your own local guidelines to answer the following questions, or use the guidelines produced by East Lancashire Health Economy (2014) for the purpose of answering the questions.

\section{QUESTION 1}

You are working in General Practice, and consulting with Mrs Kahn's three children Safia, Farheen and Kazam. They have been called in to the practice to discuss their vitamin D levels which were checked following general symptoms of sore muscles, aches and pains and. Further assessment of the children found nothing serious and low vitamin $D$ levels were deemed to be the cause of the symptoms.

The childrens' vitamin D levels are listed in the table below. State whether these levels are normal, insufficient or deficient.

\begin{tabular}{|l|l|l|l|}
\hline child & age & 25hydroxyvitaminD level & ANSWER \\
\hline Safia & 13 & 19 & DEFICIENT \\
\hline Farheen & 10 & 22 & DEFICIENT \\
\hline Kazam & 8 & 33 & INSUFFICIENT \\
\hline
\end{tabular}

\section{QUESTION 2}

For each child, state whether you would offer lifestyle advice, a prevention dose of vitamin D or a treatment dose of vitamin D.

\begin{tabular}{|l|l|}
\hline child & ANSWER \\
\hline Safia & LIFESTYLE ADVICE \\
& PLUS A TREATMENT \\
& DOSE \\
\hline Farheen & LIFESTYLE ADVICE \\
& $\begin{array}{l}\text { PLUS A TREATMENT } \\
\text { DOSE }\end{array}$ \\
\hline Kazam & LIFESTYLE ADVICE \\
& PLUS A PREVENTION \\
& DOSE \\
\hline
\end{tabular}




\section{QUESTION 3}

Suggest a dose of vitamin D for each child

\begin{tabular}{|l|l|}
\hline child & DOSE \\
\hline Safia & $\begin{array}{l}80,000 \text { units once } \\
\text { weekly for 7 weeks }\end{array}$ \\
\hline Farheen & $\begin{array}{l}6000 \text { units daily for 7 } \\
\text { weeks }\end{array}$ \\
\hline Kazam & $400-1000$ units daily \\
\hline
\end{tabular}

\section{QUESTION 4}

Produce a prescription for vitamin D for each child. You will need to state the name of the product, formulation (include strength if necessary), dose and quantity

\begin{tabular}{|l|l|}
\hline child & PRESCRIPTION \\
\hline Safia & $\begin{array}{l}\text { HUXD3 20,000 unit } \\
\text { capsules, take four } \\
\text { each week for 7 } \\
\text { weeks, 28 capsules }\end{array}$ \\
\hline Farheen & $\begin{array}{l}\text { PRO-D3 FORTE } \\
\text { 3000units/ml liquid, } \\
\text { take 2ml daily for 7 } \\
\text { weeks, 2 } \times \text { 50ml } \\
\text { bottles }\end{array}$ \\
\hline Kazam & $\begin{array}{l}\text { ABIDEC DROPS NB } \\
\text { some health } \\
\text { economies } \\
\text { encourage self care } \\
\text { instead of } \\
\text { prescription for } \\
\text { vitamins unless } \\
\text { treating deficiency }\end{array}$ \\
\hline
\end{tabular}

\section{$\underline{\text { References }}$}

Royal College of Paediatrics and Child Health (RCPCH), (2013) Guide for Vitamin D in Childhood, available online at https://www.rcpch.ac.uk/sites/default/files/2018-

03/guide to vitamin d in childhood.pdf

East Lancashire Hospitals NHS Trust (2014) Paediatric Vitamin D Guideline, available online at www.elmmb.nhs.uk 